\title{
Spice up your life - virtual communication on the experiences from using synthetic cannabinoids
}

\section{Začiniti svoj život - virtualna komunikacija o iskustvima upotrebe sintetičkih kanabinoida}

\author{
Martin Salzmann-Erikson \\ University of Gävle, Faculty of Health and Occupational Studies, Department of Health and Caring Sciences, University of Gävle, 80176 Gävle, Sweden
}

\begin{abstract}
Introduction: The body of evidence about synthetic cannabinoids and their harmful physiological and psychological effects is increasing due to laboratory research and clinical case reports. However, little attention in research has been paid to users' perceived intoxication experiences. Therefore, the insider perspective is accounted in this paper.

Purpose: The study aims to explore and describe anecdotal communication about "Spice", a synthetic cannabinoid, among users.

Methods: A netnographic methodology was applied using data from forum discussions. Results: The findings are presented in two categories: 1) communication sharing experience-based knowledge from intoxication and 2) communication sharing attitudes, norms and values. The analysis that follows posits that there is near-consensus among the posters (users who has submitted a message) that synthetic cannabinoids are associated with negative experiences and should be avoided.
\end{abstract}

Conclusions: The performativity of interactivity may be pivotal in helping frightened users make sense of their experiences. Therefore, a platform for communication among Spice users has important intrinsic value.

Key words: communication • internet drug • qualitative methods $•$ spice • synthetic cannabinoids

Running head: virtual communication and synthetic cannabinoids

\section{Sažetak}

Uvod: Znanstveni dokazi o uporabi sintetičkih kanabinoidima i njihovim štetnim fiziološkiim i psihološkim učincima u značajnom su porastu i to zbog povećanog broja provedenih/publiciranih laboratorijskih i kliničkih istraživanja. Međutim, nedostatan je obim opisa osobnih iskustava korisnika u tijeku konzumiranja opijata. Stoga se u članku opisuju unutarnja/osobna i opisana iskustva korisnika [engl. insider perspective].

Svrha: cilj je istražiti i opisati publicirane anegdote u komunikaciji u tijeku konzumiranja sintetskih kanabinoida, među korisnicima.

Metode: netnografička metodologija primijenjena na temelju podataka iz rasprava objavljenih na forumu [internet].

Rezultati: Rezultati su prikazani u dvije kategorije: 1.) razmjena komunikacijskih iskustava s naglaskom na stanje opijenosti i 2.) razmjena komunikacijskih stavova, normi i vrijednosti korisnika. Analiza utvrđuje da među konzumentima sintetskih kanabinoida koji su objavili poruke postoji gotovo jednoglasan stav u vezi s negativnim iskustvima te verificiraju da uporabu treba izbjegavati.

Zaključak: performativnost interaktivnosti može biti važan čimbenik u pomaganju korisnicima koji su uplašeni u razjašnjavanju njihovih iskustava. Dakle, platforma za komunikaciju među korisnicima sintetskih kanabinoida ima važnu unutarnju [engl. insider perspective] vrijednost.

Ključne riječi: komunikacija • internet i droge • kvalitativne metode • začini • sintetski kanabinoidi

Kratki naslov: virtualna komunikacija i sintetički kanabinoidi

Autor za korespondenciju/Corresponding author:Martin Salzmann-Erikson, R.N., Ph.D., University ofGävle, Faculty ofHealth and Occupational Studies, Department of Health and Caring Sciences, 80176 Gävle, Sweden E-Mail: martin.salzmann@hig,se

\section{Introduction}

"Spice" is a collective brand name for a dried herbal blend sprayed with synthetic cannabinoids. These blends were not intentionally produced for human consumption, although they provide those who smoke the blends with a similar drug intoxication compared to cannabis. Spice is a popular drug among adolescents and young adults, as it is cheap and easy to access [1]. Despite its well-documented risks, the media reports daily of serious cases of intoxications and resulting needs for intensive medical care.
Some studies have reported demographic data for synthetic cannabinoid users. The user population tends to be dominated by younger males around 25 years old [2-4], and their main reasons for using synthetic cannabinoid were curiosity, legality and availability $[2,4]$. The body of evidence regarding synthetic cannabinoids and their physiological and psychological effects is increasing due to laboratory research and clinical case reports [5-7]. The physiological effects that have been reported are, for example, 
tachycardia, agitation, hallucinations, hypertension, hypokalaemia, nausea, tremors, sweating, chest pains, vomiting, and seizures $[6,8-9]$. The reported psychological effects are agitation and acute psychosis $[7,10]$ as well as irritability, anxiety, paranoia, and other negative mood changes [8]. While the increasing evidence from the literature shows a rather united presentation of the physical and psychological effects of synthetic cannabinoids, which helps medical emergency staff to faster diagnose and treat the symptoms little attention in research has been paid to the micro-culture of the users. An extensive body of knowledge is lacking about important issues regarding the perceived experiences from intoxications, the users' relationships to the drug, its consequences and the users' ways of reasoning [cf. 3]. Therefore, the lack of qualitative inquiry strongly suggests the need for a study from an insider's perspective, from those who deliberately chose to intoxicate themselves and their "internal communication" about the substance and substance use. Hence, this paper aims to explore and describe the content of communication that is shared on a web-based platform about users' experiences with a synthetic cannabinoid.

\section{Material and Methods}

Design: An explorative and descriptive research design was applied to meet the research purpose [11]. A netnographic research approach was used in order to study an online micro-culture [12] Kozinets [13] developed the netnographic methodology in order to study communication in virtual communities as people share their interests and establish social bonds. In relation to nursing science, the netnographic method described by Salzmann-Erikson and Eriksson [14] called LiLEDDA was followed to collect, analyse, interpret and give trustworthiness to data.

Procedures:The first step was to locate the field, a forum on the Internet. Prior to the search for forums, some criteria for inclusion were set: 1) a forum where posters (users who has submitted a message) used Scandinavian languages; 2) the forum should provide richness in data so that the purpose could be answered; 3 ) an open forum that did not required registration to access the data; 4) high frequencies of postings; 5 ) frequent postings in the threads to ensure active communication. The large search engines Google and Yahoo were used to tentatively scan and identify different forums where communication about synthetic cannabinoids took place.

Data Collection: Several forums were identified; however, one forum was chosen, as it was considered to be the most suitable when considering the criteria of inclusion. Initially, the threads were briefly scanned to ensure that the written text was about user experiences and their communications about Spice. To ensure dependability in data [15] only threads that included the word "Spice" in the headings were included. The threads were sorted according to date, and the first 50 threads dated from present day back to about two years ago, so these were included in the data collection. In a netnographic study, it is not possible to present the "participants" with the same control as in more traditional study methodologies. Those who contribute with text in the forum are called "posters", as they post texts, and instead of using names they use an "avatar", an electronic shadow of their persona that allows anonymity.

\section{Data Analysis}

A general inductive approach was used during the first step of analysis [16]. The data consisted of 103 pages of text. At first, the data was read and reread to become familiarized with the communications. During the reading, analytic memos were written, which included hunches and clues that were identified [cf. 17]. Next, the data were read again, line-by-line, and the meanings and paragraphs in the posts were given categorizing labels. When all data were thoroughly worked through, all categories were copied to a separate spreadsheet. The texts in each category were reviewed and sorted in a first round according to their similarities and differences. For example, "I'm going to die, these are the last moments of my life, I'm really scared of death" and "getting the world's worst panic and starting to breathe horribly fast" were both categorised with texts that address the effects of the intoxication, while "the old ones were really good" and "the new kinds, they change a little molecule so it's legal. So in my opinion it's a shitty drug because you don't know what it does to your brain" were both placed in a category on attitudes about Spice. The texts that were associated with each category were then discussed and presented in the results. To ensure trustworthiness, lengthy descriptions from the data were extracted along with analytical descriptions within the categories.

\section{Ethical Considerations}

Ethical approval was not necessary since the data originates from a publicly available venue, as the forum does not require any registration, login or password. This principle follows the international ethical principles on the Internet as a research platform (see for example $[12,18]$. All posters are given pseudonyms to protect their confidentiality.

\section{Findings}

The communication was between those who wanted to share their experiences, who were considered to be inexperienced, and those who commented, who held a more experienced position. The findings are presented in two categories: 1) communication sharing experience-based knowledge from intoxications, and 2) communication sharing attitudes, norms and values.

\section{Sharing Experience-Based Knowledge from Intoxications}

The reports started with personal data concerning the poster's age, sex, height, weight, previous experience with Spice and/or other drugs, and also the specific substance if known, dosage, measured in grams or number of puffs, duration of intoxication and sometimes how many people who were involved in the situation. The reports were highly structured in chronological order and started with describing the circumstances. 
"Starting when summer vacation began, I've smoked and partied more often than during the semester. Yesterday (Thursday), I slept at my friend's after she had a little get-together, and today I woke up around 10 when another friend of ours came with a little weed. It was probably Spice, which I had only smoked once before without feeling especially affected. So we smoked a joint with Spice before I left. I took 4 hits and then said goodbye because I had to get home." [tumeric_94] Female, 23 years old.

Reports also focused on the very moment of smoking, and several reports describe the disappointment when nothing really happened. However, in several reports that disappointment changed when the drug took them by surprise.

"I take a big toke, it tastes terrible. Like someone burned incense and then gave me the ashes that are candied with something sweet. Nothing happens. I look at Kalle and Pelle, we all shrug and I take two more hits, this was within 40-50 seconds max. Then I start laughing, Pelle starts to laugh, too, laughing like idiots. Kalle is totally silent and his eyes are shut." [FrankY] Male, 19 years old

The effect of Spice was described to be highly unpredictable because in some cases it was perceived that nothing happened, while others report that the effect was instantaneous. One poster stated that Spice was so potent that is was not possible to realize the seriousness of the intoxication. There was almost a consensus about the initial effects, and these were mainly described as "being in a nightmare", as the users were not able to control themselves nor understand what was happening around them. This user reported such feelings:

My whole self feels split, ego-dead is nothing I usually talk about unnecessarily, but in this case it could very well be a form of ego-splitting, though it's a very dark version of it. Don't feel like myself at all, feels like I'm built of negative energy, angst \& hate! Fucking close my eyes, want to puke at the same time as I want to go back, my whole body screams for help, the beautiful places the wonderful memories -everything is gone, what's left is apathy, agony and worry." [weedman] Male, 22 years old.

Experiences of skewed sensory impressions affecting vision, hearing and feeling were repeatedly reported. Perceiving the world in slow-motion or as if the room had shrunk was recurred in several reports and was often associated with fear, as users found it hard to understand their states of mind as well as their bodily movements and orientation in relation to time and space.

"Everything is going in slow motion, I move my body the same way I usually do, try to lean forward, a friend takes the remote control out of my hand and my finger twitches. It feels like we're the same person. Happiness quickly takes over my body, and the pain is almost gone. Suddenly I'm hit with the thought that my life is made up, I'm someone's experiment... the panic comes and I'm breathing really fast and hard. Everything turns black." [midnight_express] Female, 19 years old.

The intoxication of the synthetic drug Spice was referred to as 'mental' and differentiated from a natural drug like cannabis (also called "cb"), as cannabis was described to be more "embodied", with a more positive association. Since
Spice was "mental", it meant that the intoxication affected the mind, mostly negatively, in terms of experiencing "looping" in time, anxiety due to feeling worthless or the sense of being fully convinced that the user would die at any moment. In one thread, a poster concurred with the reported experience:

"Just like you, I came up with a bunch of conspiracy theories, felt terrible everywhere. But even worse was that I honestly believed that I couldn't breathe. During those two hours I had to focus $110 \%$ on breathing." [JonnyH] Male, 25 years old.

\section{Sharing of Attitudes, Norms and Values}

As the first category covered the various ways that Spice users reported their experiences from [bad] intoxications, other users commented upon these narratives. Many of the posters agreed and confirmed similar experiences. For example, "23089j" confirmation the experience of a user, posting: "Recognize the conspiracy thoughts. I experienced the same thing when I smoked spice." Some of the postings contradicted the narratives and instead depicted some positive effects, though these were rare and mainly concerned the first minutes of the intoxication. In the threads, it was possible to identify a certain order of communication, where often a less experienced user reported experiences from an intoxication; thereafter, more experienced users replied to them. To a large extent, this way of communicating between "juniors" and "seniors" partly concerned confirmations or contradictions that related to the experiences; communication also went beyond such dichotomisation. In reply posts, senior users expressed their attitudes, norms and values related to how the drug ought to be used, and they advised the juniors towards alternative substances and alternative lifestyles. Also, seniors expressed their values about those who sold Spice. Based on an intoxication report, the poster "Tyfon" gave advice in the position of a senior:

I've smoked my fair share of spice and people really underestimate how strong synthetic cannabinoids are. You have to be incredibly careful when it comes to smoking spice "fast". With weed you can easily smoke two joints without much happening in the first 10 minutes. But spice is different; you get really high even after you let out the first breath 10-20 seconds. You have to respect that and take it easy if you want to have a good experience with spice. Try again and take one hit at a time until you feel like you've got a good rush! You can get really fucking messed up if you aren't careful, it's happened to me, too! [Tyfon] Unknown gender and age.

This excerpt was not discouraging the junior user to stop smoking Spice but, rather, trying to raise a warning flag and advice by sharing instructions on how Spice "ought" to be used to avoid future negative experiences. Even though the above post could be considered as drug-liberal since Tyfon shares advice for techniques for continuing usage, most advice from the postings were rather exhortations to stop using Spice and other synthetic cannabinoids. For example, one poster pointed out:

"You get totally crazy in the head from it, it's not even a good rush it's just idiotic, easily becomes psychosis. BOOM guess 
why it's cheaper? And by the way, if you start to crave grass, you should probably stop using, for your own good." [qwerty69] Unknown gender and age.

In addition to dissuading the initial poster from further Spice use, poster qwerty69 also advised an alternative lifestyle that did not include drugs at all. The communications in several threads could be interpreted as expressions of caring attitudes: seniors expressed concerns and worries for juniors. Another poster, TommyLee_007, agreed that Spice was considered harmful, but in addition the post revealed some basics fundamentals of drug culture: "spice is simply a shitty drug you stay far away from [...] I've never gotten anything good out of it either". It seemed that those who used drugs in general wanted to get "something out of it" in a positive manner and therefore tried different drugs as a kind of mental exploration. But since Spice didn't seem to fulfil that purpose, there was almost a consensus among the seniors to discourage others from future use. Other posters asserted their moral values concerning individual responsibility. This was apparent as two posters commented on an intoxication report:

"That said, I don't want to sound like a spokesperson for smoke mixes. Only that we all bear our own responsibility with regar$d s$ to reading and testing our boundaries carefully, not "Crash, boom bang in with everything at one time as much as possible!" [Ferarriboy] Unknown gender and age.

"Agree. I think Bone96 should wait a few years before getting involved in the drug mess. To start with psychoactive drugs at an early age isn't especially wise. Especially for Bone96 who obviously isn't fully developed." [united_fan] Unknown gender and age.

As seen in the communication, senior users were also affected by the negative experiences that junior users wrote about, as they asserted an older brother-like concern for those who used Spice at young ages.

\section{Discussion}

The purpose of this study was to explore and describe the content of communication that was shared on a web-based platform about experiences with synthetic cannabinoids. There is near-consensus among the posters that synthetic cannabinoids are associated with negative experiences. As previous research indicate, synthetic cannabinoids are considered to have serious negative effects on users' well-being, both physiological and psychological [6-9]; however, not all symptoms recorded in the literature were identified in the findings in this study. In stark contrast, one study reported that almost 90 percent of users had had positive experiences [4]. Sometimes, more "natural drugs" such as cannabis were praised, although examples were also identified whereas total abstinence was recommended. Serendipitously, it turned out that the communication within the micro-culture was strongly negative towards the synthetic cannabinoid Spice and towards the experiences of intoxication. Furthermore, the results show that while the less experienced users, "juniors" (regardless of their biological age) were sharing their experiences from intoxications, more experienced users "seniors" replied and commented upon these reports. It seemed that many of the users were unprepared for the effects of intoxication; they were poorly informed and underestimated the potency of the drug.

The negative attitudes that were demonstrated in the findings may be explained by the fact that Spice is thought to be cannabis-like drug, though it turns out to be far more potent. In the forum communication, the seniors reacted to the juniors' descriptions and adopted critical positions towards the juniors' imprudence and gave reprimands. The communication demonstrates a hierarchy that involved both an "older-brother position" as seniors moralized and reprimanded juniors. Nevertheless, it could be interpreted that the reprimands were not a manifestation of expressing a higher power order with the purpose of suppressing juniors. Rather, it is possible to view this kind of communication as a form of caring, with the underlying intention of protecting the others' well-being regarding future use. Similar polarization of virtual nursing components in communication between more and less experienced posters on a web-based forum of women's online support for feelings within the culture of breast enlargement were found in a study [19].

Furthermore, the forum not only served the role of providing information; the dynamics of communication also provided a possibility to make sense of the experiences [cf. 20]. The notion of making sense may be addressed to both novice users and more experienced users. With regards to the novice users, they may be curious about testing synthetic cannabinoids, but prior to doing so, they may use a forum to inform themselves through seniors. Using the forum could be a more effective alternative to deter potential users from testing synthetic cannabinoids in the first place, while formal governmental information and scaremongering do not have that effect, as the reports of intoxication are rapidly increasing. Using forums may be a way of making sense of usage and its consequences, since those who have used synthetic cannabinoids narrated frightening experiences that can be explained as the dissipation of the everyday rhythm of well-being of body, mind and spirit [cf. 21,22 ]. The forum may therefore provide more experienced users with a way to make sense of their experiences by providing the possibility to discuss them with others who have similar experiences. The performativity of interactivity could be pivotal in helping frightened users to makes sense of their experiences. Therefore, the intrinsic value of a platform for communication among synthetic cannabinoid users is immensely important and should not be dismissed and denounced "only as a forum for enthusiasm of further use" or inviting newbies. Lastly, trends in society are rapidly changing, especially synthetic drugs.

\section{Methodological Considerations}

Since only one forum was chosen to be included for data collection, it is not possible to claim, due to traditional understandings in research, that the results can be generalized outside the given context. Nevertheless, as this study does not intend to extrapolate the findings to a population outside the one studied, I argue for the potential value of gaining insider narratives from synthetic cannabinoid users 
since this methodological approach has been omitted in previous research. What provides credibility to the findings is the comparison with previously published reports and the presentation of 'thick description' to provide the reader with detailed account of the situations [23].

\section{Conclusions}

The findings clearly show that forum posters express negative attitudes towards the synthetic cannabinoid Spice since it is not giving the positive effects that users want. The communication in the forum was twofold: first, the less experienced user reported about intoxications, and, second, the more experienced users advised against the use of the drug. The forum plays an important role as it informs about the effects of the drug from first-hand, self-reported experiences, and it also provides a platform in cyberspace to discuss the negative aspects. In summary, the forum communication offers the possibility to "make sense" of the drug experiences using the posters' exchanged information related to Spice, and therefore the forum hold important intrinsic value.

\section{References}

[1] Vardakou I, Pistos C, Spiliopoulou, C 2010. Spice drugs as a new trend: Mode of action, identification and legislation. Toxicology Letters. 2010; 197: 157-162.

[2] Barratt MJ, Cakic V, Lenton, S 2013. Patterns of synthetic cannabinoid use in Australia. Drug and Alcohol Review. 2013; 32: 141-146.

[3] Papanti D, Schifano F, Botteon G, Bertossi F, Mannix J, Vidoni D, ... Bonavigo T. 2013. "Spiceophrenia": A systematic overview of "Spice"-related psychopathological issues and a case report. Human Psychopharmacology: Clinical and Experimental. 2013; 28: 379-389.

[4] Vandrey R, Dunn KE, Fry JA, Girling ER. 2012. A survey study to characterize use of Spice products (synthetic cannabinoids). Drug and Alcohol Dependence. 2012; 120: 238-241.

[5] Auwärter V, Dresen S, Weinmann W, Müller $M$, Pütz $M$, Ferreirós $N$. 2009. 'Spice' and other herbal blends: Harmless incense or cannabinoid designer drugs? Journal of Mass Spectrometry. 2009; 44: 832837.
[6] Every-Palmer S. 2011. Synthetic cannabinoid JWH-018 and psychosis: An explorative study. Drug and Alcohol Dependence. 2011;117: 152157.

[7] Hermanns-Clausen M, Kneisel S, Szabo B, Auwärter, V. 2013. Acute toxicity due to the confirmed consumption of synthetic cannabinoids: Clinical and laboratory findings. Addiction. 2013; 108: 534-544.

[8] Castellanos D, Singh S, Thornton G, Avila M, Moreno A. 2011. Synthetic cannabinoid use: A case series of adolescents. Journal of Adolescent Health. 2011; 49: 347-349.

[9] Schneir AB, Cullen J, Ly BT. 2011. "Spice" girls: Synthetic cannabinoid intoxication. The Journal of Emergency Medicine. 2011; 40: 296-299.

[10] Gurney SMR, Scott KS, Kacinko SL, Presley BC, Logan BK. 2014. Pharmacology, toxicology, and adverse effects of synthetic cannabinoid drugs. Forensic Science Review. 2014; 26: 54-76.

[11] Polit DF. Beck CT. 2010. Essentials of nursing research: Appraising evidence for nursing practice.Wolters Kluwer Health/Lippincott Williams \& Wilkins; Philadelphia.

[12] Kozinets RV. 2010. Netnography: Doing ethnographic research online. Sage; Los Angeles, CA.

[13] Kozinets RV. 1999. E-tribalized marketing? The strategic implications of virtual communities of consumption. European Management Journal. 1999; 17: 252-264.

[14] Salzmann-Erikson M, Eriksson H. 2012. LiLEDDA - A six step forumbased netnographic research method for nursing sciences. Aporia. 2012; 4: 7-19.

[15] Lincoln YS, Guba EG. 1985. Naturalistic inquiry. Sage; Beverly Hills.

[16] Elo S, Kyngäs H. 2008. The qualitative content analysis process. Journal of Advanced Nursing. 2008; 62: 107-115.

[17] Braun V, Clarke V. 2006. Using thematic analysis in psychology. Qualitative Research in Psychology. 2006; 3: 77-101.

[18] Janetzko D. 2008. Nonreactive data collection on the internet: In: $N$ Fielding, RM. Lee G. Blank (Eds.). The Sage handbook of online research methods. Sage; London.

[19] Salzmann-Erikson M, Eriksson H. 2011. Torrenting values, feelings, and thoughts-Cyber nursing and virtual self-care in a breast augmentation forum. International Journal of Qualitative Studies on Health and Well-Being. 2011; 6:7378.

[20] Ziebland S. 2004. The importance of being expert: The quest for cancer information on the internet. Social Science and Medicine. 2004; 59: 1783-1789.

[21] Newman M. 1994. Health as expanded consciousness (2nd ed.). National League for nursing Press; New York.

[22] Neuman B. 1995. The Neuman systems model (3rd ed.). Norwalk, CT Appleton \& Lange.

[23] Shenton AK. 2004. Strategies for ensuring trustworthiness in qualitative research projects. Education for Information. 2004; 22: 63-75. 